\title{
Translated Plays as a Force for Social Justice
}

\author{
Rachod Nusen (รชฎ นุเสน) \\ Lecturer, Faculty of Humanities and Social Sciences, \\ Chiang Mai Rajabhat University, Chiang Mai, Thailand \\ daydreamingism@hotmail.com \\ Kamron Gunatilaka (คำรณ คุณะดิลก) \\ Independent scholar, Thailand \\ gtilaka@gmail.com
}

\begin{abstract}
During the current political crisis in Thailand, people hold various political standpoints. Despite these different stances, the goal for many of these differences remains the same, namely, a just society. The research Translated Plays as a Force for Social Justice is an attempt to advocate the role of literature in creating social justice. The purpose of the research is to study issues of social justice in translated plays and to suggest ways in which the Thai academic community and Thai society can use plays to advocate social justice. This research studies translations of William Shakespeare's The Merchant of Venice, Bertolt Brecht's Der gute Mensch von Sezuan, Jean Anouilh's Antigone and Arthur Miller's The Crucible. The study finds that these plays pose challenging questions which help raise an awareness of the importance of social justice. Critics and theatre practitioners in the West have created a number of works on these plays that help advance social justice. Nonetheless, the issues of social justice in these plays are often ignored by Thai critics and theater practitioners and, because of this, some of them unintentionally offer an interpretation or a production, which is not in line with the concept of social justice.
\end{abstract}

\section{Keywords}

translated plays - justice - social justice - literary criticism 
บทคัดย่อ

บทละครแปลในฐานะพลังเสริมสร้างความยุติธรรมทางสังคม

ในระหว่างวิกฤตการณ์การเมืองไทยปัจจุบัน ผู้คนมีจุดยืนทางการเมืองที่หลากหลาย อย่างไรก็ตาม ท่ามกลางความแตกต่างนี้ คนจำนวนมากก็ยังมีเป้าหมายที่เหมือนกัน นั่นคือการสร้างสังคมที่ ยุติธรรม งานวิจัยบทละครแปลในฐานะพลังส่งเสริมความยุติธรรมทางสังคม เป็นความพยายาม หนึ่งในการส่งเสริมบทบาทของวรรณกรรมในการสร้างความยุติธรรมทางสังคม โดยมีจุดประสงค์ เพื่อศึกษาประเด็นความยุติธรรมทางสังคมในบทละครแปลและเพื่อเสนอแนะแนวทางที่วงวิชาการ ไทยและสังคมไทยสามารถใช้บทละครในการส่งเสริมความยุติธรรมทางสังคม บทละครแปลที่นำ มาศึกษาได้แก่ The Merchant of Venice ของวิลเลียม เชคสเปียร์ Der gute Mensch von Sezuan ของแบร์ทอลท์ เบรคชท์ Antigone ของณ็อง อานุย และ The Crucible ของอาเธอร์ มิลเลอร์ ผลการ วิจัยพบว่าบทละครเหล่านี้ตั้งคำถามที่ท้าทาย ซึ่งมีส่วนช่วยสร้างความตระหนักรู้ถึงความสำคัญ ของความยุติธรรมทางสังคม นักวิจารณ์และนักการละครชาวตะวันตกได้ผลิตผลงานเกี่ยวกับบท ละครเหล่านี้เป็นจำนวนมาก ซึ่งช่วยส่งเสริมความยุติธรรมทางสังคม อย่างไรก็ดี ประเด็นเรื่อง ความยุติธรรมทางสังคม มักไม่ได้รับการกล่าวถึงมากนักจากนักวิจารณ์และนักการละครชาวไทย และด้วยเหตุนี้ นักวิจารณ์และนักการละครจำนวนหนึ่งได้นำเสนอการวิจารณ์หรือผลงานละคร ที่ ไม่สอดคล้องกับแนวคิดความยุติธรรมทางสังคม

\section{Introduction}

Thailand has suffered numerous political crises for more than a decade. Thai people are bitterly divided and still cannot establish any political consensus. However, according to Satitniramai, Mukdawijitra and Pawakapan (2013, 140), although Thai people hold various political standpoints, $91.96 \%$ of them want a just society. This research is an attempt to advocate the role of literature in creating social justice as a means of solving, or quelling, Thailand's bitterly divided political situation. The researchers hold that drama is an appropriate means to advocate justice since it is a collaborative art. It also tends to reflect upon social problems and injustices. Moreover, translated plays open readers to unfamiliar cultures and, when these plays are performed, they do not only reach people who do not normally read literary works but also demonstrate how one can transform imagination into an event that allows viewers to reflect upon social issues.

1. To investigate the issues of social justice in translated plays 
2. To suggest how Thai society and the Thai academic community can use translated plays to advocate social justice

\section{Scope of Research}

This research studies the Thai translations of William Shakespeare's The Merchant of Venice by King Vajiravudh, Bertolt Brecht's Der gute Mensch von Sezuan by Duangporn Pongsopavichit, Jean Anouilh's Antigone by Mattani Rutnin and Arthur Miller's The Crucible by Watchara Kuptawatin. These plays are selected as case studies because each of them engages with issues which are of interest to social justice. They are also selected because they are fairly well-known in Thailand, which means that there are materials on them, such as reviews, critiques or productions that the study can use for analysis. To avoid being repetitive, the study of each play focuses on a different aspect of social justice. The research was conducted in 2017 and, therefore, any materials and productions produced after that have been excluded.

\section{$4 \quad$ Research Methodology}

This research is a study of literature as a force for social justice that uses documentary research. The researchers investigated and analyzed documentary sources and recordings to frame a discussion which responds to the research purposes.

\section{Research Framework and Concepts}

\subsection{SocialJustice}

In this study, social justice means a condition in which everyone has equal rights and opportunities. It is the right of everyone to receive sufficient help from the state and where social management should be conducted for the benefit of the most disadvantaged people. This concept is used as the framework for analyzing the translated plays discussed here. This framework comes from synthesizing ideas proposed by a number of political theorists. An early argument for the right of every one to live a decent life was delivered by Thomas Paine, the eighteenth century political thinker. Paine $(1995,149)$ maintained that the role of the state is to establish an equalitarian society by distributing wealth as "a right and not a charity". Mill $(2001,59)$ argued for the necessity to 
"treat all equally well" and Rawls (1999) proposed principles of justice based on equal rights and social arrangements that are open and benefit everyone, especially people who are least well-off.

\subsection{Literature and Social Justice}

Our research and analysis has been conducted with the conviction that literature can advance the agenda of social justice by criticizing the existing states of injustice, thereby offering the image of a possible new world and, through changing the people's perception, into one which is supportive to the agenda of social justice. This framework comes from synthesizing ideas proposed by a number of thinkers on literature. For example, Sidney $(2000,121)$ believes in the role of literature to "teach and delight" and to offer a view of "what may be and should be". Sinfield $(1983,1)$ suggested the role of literary works as "interventions" which help society "interpret and constitute itself". Banchoetsin (1974), a Thai Marxist critic, argued that literature can give people hope, offer new possibilities and change society. Satha-Anand (2009) also argued for the role of literature in questioning and challenging unjust perceptions. Meesuk (2000), a lecturer in Thai, considered drama as an effective ideological apparatus.

There is some evidence which shows that literature can make people rethink their positions and act to create a fairer society. During the American Civil War, after reading Harriet Beecher Stowe's Uncle Tom's Cabin, James Baird Weaver decided to join the Union to abolish slavery (Morritt 2011, 153). Stowe's novel also emboldened Abraham Lincoln to tackle the problems of slavery (McPherson 1988, 89). Furthermore, literature can create a sense of belonging and sympathy towards marginalized people. Garden $(2007,258-260)$, the author of Annie on my Mind, a novel about a romantic relationship between girls, maintains that her book helps people understand homosexual people more and "[l] esbian or questioning teens usually write about how Annie has helped them to feel less alone, to like themselves, to have hope".

\subsection{Issues of Injustice in Thailand}

The following social problems are the target of study because they correspond with issues explored in the selected plays.

5.3.1 Cultural and Identity Injustice in Thailand

This research believes that the concept of "Thainess" is the root of cultural and identity injustice because this concept is too narrow and exclusive. As a result, minorities in the country, whether in terms of race, religion or sexual identity, are often marginalized. Tejapira (2015) discussed how the notion of "Thainess" 
has persisted with an unchanging and empty nature. Suveeranont (2015), a designer and thinker, and Archavanitkul and Vajanasara (2008) drew attention to the narrow-minded and discriminatory nature of "Thainess". In a similar vein, Winichakul (2017) drew our attention to the history of the oppression by the Thai state towards minority groups.

\subsubsection{Economic Injustice in Thailand}

Inequality and the practice of trickle-down economics by Thai governments are at the heart of economic injustice in Thailand. Ananapibut (2014), a lecturer in economics, illustrated Thailand's high level of economic inequality. Phongpaichit (2014) discussed Thailand's highest level of economic inequality compared to other ASEAN countries, and its effects on social conflict. Aeusriwong (2012) discusses the hostile attitude of Thai people towards state subsidies and offered a discussion on Thailand's trickle-down economics.

\subsubsection{Political Injustice in Thailand}

Political injustice in Thailand exists due to the fact that, in the current political crisis, the state has failed Thai people in its ability to provide positive political goods, namely, stability, safety and political participation. People hold contradictory political standpoints and have different concepts of what a "perfect" democracy looks like. They are not prepared to listen to others who have different opinions and refuse to see the drawbacks of ideas or political players who they are supporting. Tejapira (2010) provided an insightful discussion on positive political goods and how the Thai state has failed to deliver them and the one-sided blindness of both red-shirt and yellow-shirt supporters. The following political players illustrate the ideology of yellow-shirt sympathizers: Limthongkul (2011), the PDRC Foundation (2017) and Phiriyarangsan (2006). The following political players illustrate the ideology of red-shirt sympathizers: Prompan (2016), Satitniramai, et al. (2013), and Pakeerut (2015).

\subsubsection{Injustice in Thailand's Legal System}

The issues of injustice in Thailand's legal system include: legal inequality before the law between privileged and underprivileged people, the abuse of the law for personal or political advantage and the undemocratic nature of legal institutions. Wasi (2000), Uwanno, Prokati, Phonlawan, and Phakdithanakun (2000) and Ua-amnoey and Khatikarn (2011) have drawn our attention to a number of serious problems in Thailand's legal system. Through her research, Phoprom (2007), a judge, showed inequality before the law. Saengkanokkul (2016) and Setabutr (2015) noted the problem of abusing the law for personal or political advantages. Pakeerut (2015) discussed the undemocratic nature of legal institutions in Thailand. 
Venice Vanit was translated, in 1916, by King Vajiravudh, whose inspiration for translating the play may have been prompted by his attendance at a performance of this play while studying in England. According to Malakula (1996, 254), on 19 July 1902, Vajiravudh was in London and attended a production of The Merchant of Venice. This production must have been the farewell performance of Henry Irving who, as Terry $(1908,179)$ commented, played Shylock as a "[h]eroic saint". According to Hartnoll $(1983,506)$, the last time that Irving played Shylock was on 19 July 1902 at the Lyceum in London.

Nevertheless, due to his political agenda, the Shylock that the King presented was rather different from that of Irving. As Tungtang $\left(2011,5^{0}\right)$ states, the King's reason for translating The Merchant of Venice was as follows: "Considering that Shakespeare's plays have already been translated into most European languages, and even into Japanese, I feel a bit ashamed of the fact that we have not yet had any translated texts (of Shakespeare's works) in Thai". According to Chancharoensuk $(2011,4)$, translating Shakespeare was the King's attempt to advocate his role as the ruler who had civilized the country. It also does not appear to be a coincidence that the first Shakespearean play which the King translated includes a Jewish character who tries to harm people in the majority group. The King's distrust of Jewish people was expressed in his pamphlet, The Jew of the Orient, in which Asvabhahu (1985), King Vajiravudh's pen name, warns Thais to beware of Jewish and Chinese people because they are too proud of their race and are untrustworthy.

From the start, Venice Vanit is part of a nationalist project to construct an exclusive "Thainess" which is hostile towards minorities and, sadly, this attitude is apparent in a number of interpretations of the play today in Thailand. For Sangtaksin $(2005,218)$, Shylock is evil while the Christians are virtuous. Several critics have condemned Shylock as a greedy man (Department of Curriculum and Instruction Development 1984; Sangtaksin, 2005, 219). Rungsakul $(2017,83)$ even wrongly uses the word "Jewness" to describe Shylock's greed. A number of critics have also accused Shylock of being vengeful and merciless (Department of Curriculum 1984; Sangtaksin, 2005, 220). Furthermore, as Chantornvong $(2004,312)$ claims, the homoerotic bond between Antonio and Bassanio is condemned as "unnatural" and "harmful to the institution of family".

Similarly, mainstream media in Thailand have been insensitive to the racial and religious conflicts in Venice Vanit. In 2006, Broadcast Thai Television presented the trial scene of Venice Vanit as a play within a play inJan AeyJanJao, a Thai drama series. In this series, Venice Vanit was presented as a didactic play. Worathep, Jan Jao's grandfather, tells her that the play shows the danger of being 
vengeful and how vengeful people like Shylock are inevitably punished. As the story is taken out of context, the series unintentionally creates the image of Shylock as "the other" who is unreasonably evil.

Stage productions in Thailand often ignore the issues of racial conflict and discrimination in Venice Vanit. In 2015, students at the College of Dramatic Arts, Bunditpatanasilpa Institute, performed the trial scene. Before the performance, a summary of the story was narrated via audio. This narration emphasized Shylock's hateful nature and cruelty without explaining that he hates Antonio because the racist Antonio often abuses him verbally and physically. This summary would have made spectators take the Christians' side. Moreover, in this production, the "otherness" of Shylock was emphasized through his costume and gestures. He was presented as a hunch-backed, strange man who wears a blond wig and a witch-like nose. As Tungtang (2011, xxvi) explains, this presentation was in line with the tradition in Thailand to base "the character of Shylock on the famous character of Jujaka, a greedy old Brahmin beggar from Vessantara Jataka".

The identification of Shylock as a Shakespearean Jujaka made it difficult to deconstruct the stereotype of Jews as greedy people. As a result, the members of audience who attended the production unsurprisingly took the Christians' side against the Jujaka-like Shylock. The spectators laughed when Gratiano mocked Shylock. Laughter could still be heard even at a harsh and offensive statement like Gratiano's "You, pagan, your time is up".

Shylock was also portrayed as a villain in the production of Venice Vanit by the Phaya Thai Palace Preservation Foundation and Women's Professional Association at the Phaya Thai Palace, Bangkok, on 27 February 2016. In this production, Shylock entered the stage with an ominous sound effect usually used in Thai soap operas to signal the approach of evil figures. His entry changed from a blue background to a red one signifying blood, violence and danger. He dressed and walked like a villain. These elements were enough to confirm to the spectators that this being was an alien who could not be trusted. Hence, for them, it might have seemed justifiable that, after being forced to convert, every character yelled at the alien and forced him to leave the stage. In this performance, racial discrimination was hardly questioned.

Reading Venice Vanit through the ideology of "Thainess" which harbors suspicions of "the other" often leading to the reproduction of the evil "other" versus the virtuous "us". Nang Sue An Kawi Niphan [Handbook for Reading Venice Vanit] (Department of Curriculum 1984, 22) maintains that Shylock and Portia are as different as black and white. To create social justice, it is necessary to deconstruct this binary opposition and recognize that, in fact, "we" and the 
"other" are not that different. There are many pieces of information in Venice Vanit which support this approach. One can argue that Antonio is not a threat to the family institution. In fact, it is he who facilities the journey of Bassanio and Gratiano to their future wives.

As shown above, Shylock is often accused of being mercenary like Jews allegedly are. Nevertheless, in this play, Christians are also apparently mercenary. Nang Sue An Kawi Niphan (Department of Curriculum 1984) justifies Bassanio's motivation for going to Belmont as an act of love. In fact, Bassanio never says that he loves Portia. On the contrary, he accepts quite bluntly that he wants to marry Portia because she has "a large heritage" $(1.1 .23)^{1}$ which is enough to pay his debts. It is not easy to judge between a man who makes a living by taking interest from loans and a man who marries in order to get rich; who is more mercenary?

A number of Thai critics and productions have condemned Shylock as a vengeful and merciless man when he refuses to drop his case against Antonio in the trial scene but characterize Gratiano, who threatens to hang and behead Shylock, merely as a "funny" man (Sangtaksin, 2005, 224). It is not hard to imagine that if Gratiano were Shylock and had the chance to take revenge, he would do exactly as Shylock. Moreover, to consider Gratiano's verbal abuses as merely "funny" jokes might mislead the reader into thinking that it is acceptable to use dehumanizing language, such as "you, dog" (4.1.160) and "you, Jewish devil" (4.1.172), against a person from a different culture.

The line between merciful Christians and heartless Jews becomes blurred when one thinks of Shylock's accusation in the trial scene:

Your Grace, please listen.

These men own slaves

That they buy from the market, and shave their heads,

Use as dogs or mules,

Without any trace of mercy

As these slaves have prices.

[My translation, 4. 1.157]

The will to sacrifice mercy for economic interests is certainly present in every human being, regardless of his or her race.

1 Shakespeare, W. 2005.Venice Vanit, translated by Vajiravudh, the King. Bangkok: Aksoncharoenthat. All quotations from or references to the translated play will be to this edition and the act, scene and page number will be referenced parenthetically. 
To regard Portia as an impeccably virtuous lady is an exaggeration. Because Portia is the one who delivers the "mercy speech", Nang Sue An Kawi Niphan (Department of Curriculum 1984) claims that she is merciful and, in the trial scene, she tries her best to persuade Shylock to show mercy. In the same way, Rungsakul $(2017,91)$ states that she learned at a very young age from Portia about justice and a due respect of law. However, the law that Portia practices is apparently unjust and discriminatory against Jews. Moreover, it is noteworthy that, before delivering the "mercy speech", she assures Shylock that his case is lawful and Antonio is in a disadvantageous situation (4. 1. 163) and if he presses his case, Antonio will "surely lose" (4. 1. 166). This assurance naturally encourages Shylock to press the case because he believes he is going to win. Thus, it is reasonable to regard her speech as a trap. Portia knows perfectly well that, no matter what Shylock decides to do, he will not get it his way. What she does in the trial scene is far from being just and honest. The play shows that both Jews and Christians do what they do not because they have an inherent nature which sets them apart from other people. When difficult situations arise, people, no matter what their race, can do horrible things. All of them can be mercenary, deceitful and unforgiving.

It is unfair to condemn Shylock without acknowledging the pressure that he and other Jewish characters face in a racist society. There might be a connection between ignoring Jewish characters' suffering and failing to understand cultural tensions in the provinces of Thailand's deep south. In 1989, Rutnin staged an adaptation of The Merchant of Venice which intentionally downplayed the religious and racial conflict. Rutnin $(2001,17)$ later justified her decision by maintaining that Thailand has no such problem because this country "gives freedom for people of all faiths". The sad irony is that, not long after this, violence in the deep south erupted again and has continued until this day. As Tamthai and Boonchu $\left(2008,103^{-104}\right)$ explain, people from the other parts of Thailand and the state often ignore problems and violence in the deep southern provinces because people in this area are not part of their imagined “Thainess".

The changing perception of the original play clearly illustrates the possibility of using Venice Vanit to change people's hostile attitudes towards "the other". As Mahood $(2003,47,51)$ maintains, after 1900, more and more critics read Shylock sympathetically and, since the 196os, the homoerotic issue in the play has been explored more openly. Now the issues of racism and homoeroticism in the play are no longer marginalized. In 2004, Michael Redford filmed the Merchant of Venice and highlighted the sufferings of Shylock, a victim of racism, and Antonio, a lonely, aging gay. In 2002, Don Selwyn released the Maori 
Merchant of Venice filmed in New Zealand. This film reminds the audience of the similarity between the forgotten plight of the Maoris and that of the Jews. As McDougall $(2011,98)$ noted, "at the time the film was released, a local layer of significance is likely to have been added for New Zealand audiences. In a well publicised speech towards the end of 2000, Maori MP Tariana Turia used the term 'holocaust' to refer to the attrition of the Maori population that occurred through colonisation".

The possibility of using Venice Vanit was also illustrated in the aforementioned production by the College of Dramatic Arts, Bunditpatanasilp Institute in 2015. As mentioned above, the synopsis provided before the performance was unfair to Shylock and, at the beginning, spectators evidently took the Christians' side. However, their feelings seemed to change when Shylock was really in trouble and everyone else seemed to be enjoying his pain. The playgoers' laughter was perceptibly quieter when Gratiano's threat sounded more and more serious. The playgoers lapsed into complete silence when Gratiano called for an executioner to hang "this damned". The production ended with the image of a heart-broken old man collapsing in the center of the stage, surrounded by hostile, powerful Christians. It is impossible to know whether this pitiful image was enough to make the spectators redress their prejudice against "the other", but it clearly aroused their sympathy. This reaction seems to confirm the argument of Yuvajita $(2009,34)$ that the trial scene often makes the readers/ spectators sympathize with the loser and this feeling is the first step in creating harmony and peace. When one emphasizes this message when discussing this play in the classroom or mounting a production, Venice Vanit can help people from different races or cultures live with dignity and achieve social justice.

The Good Person of Szechwan as a Force for Economic Justice

According to Nagavajara $(1983,127)$, Brecht wrote Der gute Mensch von Sezuan during the Second World War to question whether goodness was still a workable ideal in the present world. To survive economic hardship, Shen Teh, "the good person", becomes a prostitute and invents a second self, the mean Shui Ta, her male cousin, to protect herself from time to time. The Thai version of the play, translated by Duangporn Pongsopavichit, starts with the quest of three Gods to find a "good person". It is clear that these Gods are useless and incapable of even taking care of themselves. After the quest, they are "exhausted and experienced a lot of terrible things. The First God gets an injury on his head. Another one lost his leg from catching it in a trap and all of them lost 
their shoes" (Interval, 129). ${ }^{2}$ Moreover, in the last scene, when Shen Teh asks them how she can protect herself from $\mathrm{Shu} \mathrm{Fu}$, a powerful man who is trying to marry her against her will, and raise her baby in a world full of starving people, the First God cannot do much except give her some vague advice to "be a good person and then everything will be fine" $(10,141)$. This play questions the capacity of Gods and religious teachings to tackle problems in the real world.

The play also demonstrates that poverty and economic inequality produce many social problems. To survive, homeless people tell their boy to steal bread and Sun, an unemployed pilot, is prepared to hand out bribes in order to regain his position. At the same time, wealthy characters like Shu Fu and Mrs. Mi Tzu, a landlord, are above the law. When Shu Fu hits Wang, a poor water seller, no one dares to be Wang's witness because Shu Fu is "very powerful" $(4,59)$. To help Shui Ta, her business partner, to win a murder case against him, Mrs. Mi Tzu sends a fat duck to a judge who has a connection with her. The play encourages the reader/audience to see an interrelation between economic injustice and a dysfunctional society.

Nonetheless, the play does not suggest how to solve this problem. In this play, Brecht (2014) intensively uses the Verfremdung effekt, also known as the alienation effect, to make the audience realise that what they are witnessing is unnatural and changeable. Brecht wants his audience to be aware that what they are seeing is a performance and to distance themselves from it. Hence, they will not be overwhelmed by characters' emotions but rationally analyze the situation in front of them.

The V-effect is used from the very beginning when Wang enters the stage and directly addresses the audience, "I'm a water seller" (Prologue, 5). This technique is repeated throughout the story by many characters. To emphasize the nature of role-playing, at one moment, seeing Shen Teh's lover approaching, Shen Teh in the guise of Shui Ta forgets himself and starts acting in the woman-like manner of Shen Teh. Sometimes, Shen Teh becomes Shui Ta by wearing his mask in front of the audience.

That the V-effect is designed to urge the audience to think about what they are seeing and compare it to the world outside is apparent in the epilogue.

What should be done

So a good person can survive in the world?

2 Brecht, Bertolt. 2005. The Good Person of Szechwan, translated by Duangporn Pongsopavichit. Chiang Mai: Faculty of Humanities, Chiang Mai University. All quotations from or references to the translated play will be to this edition and the screen and page number will be referenced parenthetically. 
Ladies and gents, please help us imagine the ending.

There must be a good ending. There must be, there must be, there must be.

(Epilogue, 145)

This play believes that poverty is not inevitable and people can change things. As Brecht $(2014,86)$ explains, "the concern of epic theatre is thus eminently practical. Human behaviour is shown as alterable, people as dependent on certain political and economic factors and, at the same time, as capable for altering them". For Brecht $(2014,112)$, epic theatre is "an affair for philosophers, at any rate the sort of philosophers who wish not just to explain the world but also to change it". This expression is undoubtedly a paraphrase of Marx $(1976,65)$ who famously declared: "[t]he philosophers have only interpreted the world, in various ways; the point, however, is to change it". The Good Person of Szechwan was designed to be a laboratory for generating socialist ideas to stop the unfairness of capitalism.

The play demonstrates two ways of dealing with poverty and corruption through the actions of the two main characters: Shen Teh and Shui Ta. Shen Teh responds to the cruel world by being a "good" person and giving things to poor people. As Wang maintains: "no one leaves her shop without taking a bit of tobacco with them, though they have no money to buy it" (Interval, 51 ).

Nonetheless, the play does not suggest that what Shen Teh does is a way of making society better. There are too many people who need help. Without Shui Ta's help, Shen Teh would go bankrupt in no time. Moreover, that what she does is harmful in the long run is shown by the cough of the Unemployed Man who smokes Shen Teh's free tobacco. The charity that Shen Teh gives undermines social justice since a private charity establishes a patron-client relationship in which the patron has power and privilege over the client. It is not surprising that Mrs. Mi Tzu, a powerful landlady, is the president of the charity foundation in town. The unequal relationship between the patron and the client is notable when Shen Teh playfully taunts the homeless people in her shop, who are complaining that she gives away too much tobacco, saying that if they do not stop complaining she will force them out and take back the rice that she has given them. Although she does not take this threat seriously, it still highlights the inequality between them. The fact that Shen Teh can get rid of the homeless people whenever she feels like it shows that, under the patron-client system, the life of the client is never fully secure.

Charity also creates an image of the recipient as being incapable and inferior. Shen Teh describes the homeless people who stay with her as follows: 
They do not speak anymore. If we put them somewhere They stay put and become our burden.

Nothing can move them.

Only the smell of food can make them turn.

$(4,61)$

For Shen Teh, these people are not really humans but animals that live by instinct. The dehumanization of poor people naturally leads to discrimination. The Policeman stigmatizes all poor people, who accuse Shui Ta of murdering Shen Teh, as "the bad people of the city" $(10,133)$. It is not likely that people who are stigmatized like that will be treated fairly by the judicial system. Justifying discrimination against charity recipients can be seen in Thailand. Phi Tu, a political commentator, (2008) once remarked that charity recipients are worse than baboons because they do not know how to feed themselves, hence, it is ridiculous to give these "stupid" people the right to vote.

While Shen Teh responds to the problem of poverty by being generous, Shui Ta survives by being tough and self-serving. He convinces himself that the problem of this city is "too big for anyone to deal with" $(2,31)$ and that exploitation is inevitable (Interval, 65); it is sensible to be selfish. When he sees a little boy desperately scavenging for food, it justifies his intention to "separate himself from other people" $(7,104)$ and look after only his own baby. The following is the reason Shui Ta gives Wang for refusing to be Wang's witness: "It is my principle not to interfere in the conflict between neighbors" $(5,75)$. In the end, Wang cannot find anyone to help him and Shu Fu does not have to take any responsibility for breaking Wang's hand. In Shui Ta's world, underprivileged people are totally defenseless.

Shui Ta believes that, "to stay safe in this society, one needs luck, ideas and friends" $(2,40)$. Therefore, he often gives away tobacco. Nevertheless, he gives it not to poor people but to the Policeman, who, in turn, helps him to get rid of the homeless people in Shen Teh's shop. It is not surprising that when Shui Ta is charged with murdering Shen Teh, the Policeman is more than eager to defend this "good man" $(2,34)$ by assuring the judges that Shui Ta is a "lawabiding" man $(10,133)$.

Shui Ta is better than Shen Teh in "encouraging" the poor characters to work. However, the work that Shui Ta offers them is a long way from advancing economic justice. Under his watch, the business runs so exceptionally well that, before long, everyone nicknames him "the king of tobacco" $(10,132)$. Nonetheless, the living standard of the poor characters, who work hard for him, is hardly improved. The small room that Shui Ta provides for them is wet, musty, old and dirty and their wages are low. 
The economic injustice of Shui Ta's world is well illustrated at the end of scene 8. While the workers pass on the heavy baskets of tobacco, "Shui Ta is smoking his cigar and saunters by" $(8,117)$. In this scene, the play makes the reader/the audience question whether it is fair that people who work so hard have to live in poverty while people who do nothing get everything. As Shen Teh admits, what Shi Ta does is not creating jobs but exploiting vulnerable people $(10,139)$.

This kind of exploitation is not something "natural". As Jameson $(1998,139)$ explains, the economic system in The Good Person of Szechwan is a "precapitalist" one. According to Marx $(1965,67)$, this system is based on "wage labor" and was established after the "dissolution both of free petty landownership and of communal landed property". Shen Teh and other poor characters are part of the large number of free laborers who moved to work in big cities after the dissolution of communal lands. Since they have nothing but their labor, they are vulnerable to exploitation. The play shows that both Shen Teh's charity and Shui Ta's low wages are not the way to establish economic justice.

The Good Person of Szechwan is quite well-known in Thai literary circles. There are at least 3 translated versions of this play. There were also a number of productions and adaptations in Thailand, such as, the production in 1979 by Pantoomkomol at Chulalongkorn University.

Pantoomkomol $(1985,80)$ was knowledgeable about the goal of Brecht's epic theatre to make the audience realize the unbearable injustice in the world and of the function of the V-effect to make the audience keep a distance from the performance. However, the spectators of her production did not seem to be concerned much about the social issues in the play. They thought the production encouraged people to have faith in doing good things (Suppha, 1979, 37; Klinchang, 2001, 85). Klinchang $(2001,87)$ believes that the production showed the nature of human beings to be always exploitative. Pantoomkomol (1985, 82) herself also believes that the most impressive thing in Brecht's play is that it tells us about the "unchangeable" nature of human beings.

It is clear that there was a contradiction between the play which was written for stimulating social change and the director who believed that people do not change. The outcome then was confusing. As Nagavajara (1996, 111) has stated: "under the circumstances prevailing in Thailand at that time, the social and philosophical message of the work did not come through in full". Since the whole production suggested that human beings do not change, it was rather pointless that the Epilogue asked the spectators to think of a way to make the world a better place. For Nagavajara (1996, 110, 106), what this production tried to do was to "de-politicize" the play and present it in "an unabashedly 
Aristotelian interpretation, in spite of the erudite programme notes on the subject of 'Epic theatre".

It is worthwhile keeping in mind that, according to Nagavajara (1996, 96), Brecht was imported to Thailand as part of the "progressive" ideas which were booming after October 1973, while Pantoomkomol's production was mounted in 1979, when there was widespread fear of the rise of communism in Thailand and a number of "progressive" people were being arrested under the AntiCommunist Act (1952) which made it illegal to promote communist politics or economics. As Nagavajara $(1996,107)$ recalls, a hostile attitude towards Brecht as a threat to "the nation, religion and monarchy" could still be seen in an academic discussion at Silpakorn University in 1984.

Now that the threat of communism has long since passed, it is time for the Thai academic community to openly discuss the economic injustices that the play portrays. Entertaining the idea of the unchangeable nature of human beings unduly blunts the play's political edge. It is right to regard "Shu Fu as a symbol of corruption" as Suppha $(1979,38)$ did. Nevertheless, the play suggests that he corrupts not because he is evil by nature but because his wealth makes him unaccountable. Several critics have praised Shui Ta for creating works for poor people (Klinchang, 2001, 82-83; Nagavajara, 1983, 129-130). However, the play clearly shows that working for Shui Ta does not help the poor characters to live a decent life.

The history of the play in its English version proves that to mount an effective production of the play one needs to engage with its political economics. According to Eddershaw (2002, 89), the English productions at the Royal Court in 1956 and at the Citizens Theatre in 1990 were unsuccessful while the one in 1977 in Newcastle was a success because it engaged with the political economics in the play. The cast knew that they "needed to understand the social reality of the poor people in the play in order to present them as credible and human" and they had to help "the audience understand their needs and their behaviour". In order to produce a powerful production, the play demands theatre practitioners to pay close attention to the issues of poverty in their society. Another successful production was performed in 2016 in Baltimore. According to Deville (2016), the production applied "Brecht's socio-political commentary to inner city Baltimore" by creating a set of "rowhouses" which made the stage look like Greenmount Avenue, a neighborhood in the city. Hence, the director managed not only to explore "the oftentimes oppressive relationship between a society's economic system and the self" but also emphasize "the parallels between Brecht's play and the struggles faced by low-income residents" in the town. The spectators were well-entertained and laughed a lot which proved "the production's capability of making Brecht's anti-capitalism criticism appealing 
to an audience that sees theatre as a medium for entertainment above anything else".

The success of the production in 2016 reveals the potential of the play to be a force for economic justice in Thailand since it directly challenges economic inequality and Thailand's trickle-down economics which depends on cheap labor. The play suggests that people can stay virtuous only when there is social justice. A production of this play which, as with the one in Baltimore, unabashedly questions economic injustice is badly needed.

Antrakani, a translation of Jean Anouilh's Antigone, by Mattani Rutnin was performed shortly before the $6^{\text {th }}$ October Event in 1976 . Due to alterations in the translated version and the political climate at that time, Rutnin's production was quite controversial. The play focuses on the conflict between Antrakani (Antigone) and Khirithon (Creon) after Antrakani has buried her brother's body against Khirithon's orders. The transgression reflects the very different views towards life of the two characters.

The concept of "aesthetics" developed by Jacques Rancière is helpful in explaining the conflict between Antrakani and Khirithon. According to Rancière $(2009,1)$, "What aesthetics refers to is not the sensible. Rather, it is a certain modality, a certain distribution of the sensible". As Charoensin-o-larn (2008, 237) explains, for Rancière, aesthetics regulates what one can tolerate, do, talk about and see. It is inseparable from politics. As Rancière $(2009,5)$ explains, "[W]hat I call the politics of aesthetics [...] means the way in which the aesthetic experience - as a refiguration of the forms of visibility and intelligibility of artistic practice and reception - intervenes in the distribution of the sensible".

For Rancière $(2010,152)$, literature plays an important part in "politics" because it "is involved in the partition of the visible and the sayable". As Rancière (2010, 157-158) maintains, literature is democratic since it is "the mute letter" that speaks "to anybody" and "anyone can retrieve and use in his or her way".

Antrakani is an exemplar of the role of literature in creating a discussion, which lets anyone speak, and reframe a new aesthetics which is wider and fairer. The aesthetics that Antrakani holds is based on "the logic of politics" while that of Khirithon is based on "the police logic". As Charoensin-o-larn (2008, 2007-2008) explains, for Rancière, while politics works under the logic that everyone is equal, police logic is about hierarchy, domination, oppression, exclusion and the dismissal of politics. 
The world of Khirithon, based on police logic, is a place where people are and should be unequal. The hierarchy in his world is well illustrated from the positions of characters when the play starts. Khirithon, as the President, stands on the top stair, below him are his relatives and favorites, and on the ground are the three guards. Commoners are not on the stage. They are invisible and voiceless.

In this world, the power of the President is indisputable. He is the law. If anyone commits an atrocious act under his order, they are deemed "innocent" (17). ${ }^{3}$ Khirithon has an aesthetics which is hierarchal and exclusive. He describes his duty as follows:

Now our country is going down. Someone must make a sacrifice and be its captain. [...] Every crew is drowning. Why? Because everyone thinks only of themselves and all of them are short-sighted. [...] I must grab the tiller and make the ship go straight. [...] I must give orders and if someone does not comply, I shoot them all. [...] At that moment, everyone is nameless. People who are killed are nameless. Even we are nameless. What matters is the ship and the storm. (108-110)

Khirithon imagines that the whole country moves because of him and everyone else is selfish. He believes that, to establish order, people should be quiet and obedient. Violence and deceit can be used for the sake of the whole country.

Khirithon's aesthetics excludes young people, women and commoners from politics. The assumption is that they do not want to participate in politics and this is best because they should not. If any of them tries to do otherwise, it means there is something unusual going on. They might be used or they might have "psychosis" (89), as Khirithon says Antrakani has. For Khirithon, the place for women is at "home" and in the "garden with children" (124), and people are "idiots" (103) who need to be forced to keep in line. As his guard maintains, "If I listen to people who complain about the state of our country, I won't have time to work" (74-75). Khirithon's aesthetic only values the command of people from a higher status while other voices are regarded as noise.

Nonetheless, the play also features another aesthetic, that of Antrakani. For her, everyone is a human who can think and question (129). Under this aesthetic everyone, including a young woman like her, can argue with the

3 Anouilh, J. 1976. Antrakani, translated by Mattani Rutnin and Suchawadee Tantawanit. Bangkok: Duangta. All quotations from or references to the translated play will be to this edition and the page number will be referenced parenthetically. 
President. The world of Antrakani is horizontal and social division is flexible. As she tells the nurse, "Today I must not be a child" (31), she can be a child when being around the nurse and be a mature person when she has to go out of her "house" to argue with the President. For her, since Khirithon did many dirty things for political gain, he is not a great man but "rubbish" (131).

The aesthetic of Antrakani sees a decent life as life with "equality" and the "liberty" to "refuse" evil things (104), whereas the aesthetic of Khirithon prioritizes order, "responsibility" and "duty" (104). Both of these views are reasonable and the argument for and against each view is the focus of Antrakani.

The fact that both Antrakani and Khirithon have the opportunity to fully express their views makes the play a perfect work to advocate political justice. The long argument between the two characters gives the reader/audience a chance to listen to the reasons of each character. This has the potential to broaden one's horizon to acknowledge the existence of people with different political standpoints. Seeing and listening is the first step to creating a sustainable political justice.

The force of this play could be seen in its first production in 1976. Rutnin, the translator and producer, maintains that she was politically "impartial" (cited in Thongtawee, 1990, 145) and made some changes only to make the meaning clearer (cited in Phaolaungthong, 2004, 172). However, some spectators doubted her impartiality.

Khrueapradap and Yannawa (cited in Phaolaungthong, 2004: 174-175) saw the production as a right-wing attack on leftists. Ratsamee Phaolaungthong (2004: 167, 169) also believed that the production was the producer's ideological apparatus as Antrakani was portrayed as a more confused character than that in Anouilh's play. In the translation, she becomes a representative of people who blindly follows their ideals. For Parichat Jungwiwattanaporn (cited in Phaolaungthong, 2004, 178), Rutnin's revision makes Antrakani, a supposedly freedom-loving person, become a politically irresponsible person. Even Nagavajara (2004, 723-724), who was "impressed" by the production, doubted its "impartiality".

It is noteworthy that the image of Antrakani as an irresponsible person goes in line with Rutnin's attitude towards the politically active students in 1976 . According to Rutnin (cited in Thongtawee, 1990: 138, 140), the students were "unwittingly" "used" as a political tool. They were "ignorant" and "heedless", and did whatever seemed to be fashionable at the time. She was frustrated and this was the reason that she mounted this production.

In Rutnin's version, Antrakani maintains that she refuses to obey Khirithon because she refuses to accept anything wicked and she does not care what damage it may bring (104). This explanation creates an Antrakani who is more 
irresponsible than Anouilh's Antigone, who says: "I can say no to anything I think vile, and I don't have to count the cost" (35). ${ }^{4}$

At the same time, Rutnin admits that, because of her experience, she feels sympathetic towards a senior like Khirithon who has had to bear the burden and make a sacrifice for the greater good (cited in Thongtawee, 1990: 52). This attitude is reflected in her translation. Anouilh describes Creon as one who "practices the difficult art of a leader of men" (4). Mattani expands this description by adding that he decides to be the leader to establish "order in the country" and lead it out of "crisis" (11). This production was broadcast by the Royal Thai Army Radio and Television Channel 5 one month before the $6^{\text {th }}$ October Event. It does not seem to be unreasonable to believe that it was a proestablishment production.

Nevertheless, ironically, the supporters of the establishment did not like the production either. As Rutnin (cited in Thongtawee, 1990, 147) maintains:

There were people from the Red Gaurs. They came and tore up our posters. They said I wrote and mounted this production to criticize rightist movements. Leftists said I invited soldiers, people from Chulachomklao Royal Military Academy and Royal Thai Navy to attend the production because I was a rightist. Something like that. People from the Red Gaurs also said I was a leftist.

Tearing up posters suggests not only a severe lack of toleration towards people with different political standpoints but also an inclination to quell their voice. This aesthetic finally led to the $6^{\text {th }}$ October Event in which students were massacred without mercy since, for some, they had no longer been seen as humans.

Antrakani can play a role in preventing this kind of tragedy from repeating itself. Although it is slightly revised, the translated play still can be a force for political justice. It opens a space for argument between two completely different political views, which challenges the reader's political standpoint, whether he or she is on the left or right of the political spectrum. The play makes it necessary for the reader/the audience to "see" and "listen to" people with different worldviews. As a reviewer of a production in English at the Fusion Theatre in 2017 put it, though his sympathies resided with Creon, he could not "help admiring Antigone's resolve and stubborn defiance" (Kahn 2017).

4 Anouilh, J. 1946. Antigone, translated by Lewis Galantière. New York: Random House. All quotations from or references to the original play will be to this edition and the page number will be referenced parenthetically. 
Therefore, this play directly tackles what Tejapira (2010) calls the one-sided blindness of red-shirt supporters and yellow-shirt supporters. It shows that both people like Antrakani and Khirithon have their own valid reasons. Having students argue for or against Antrakani is a good way to start a debate about politics because the fictional nature of the play allows them to detach themselves and look at things objectively. This activity can help them to "see" people from the opposite side as humans with voices. This, perhaps, will lead to the realization that not only order and transparency but freedom and election are also desirable. Having a government which is not elected by people or responsible to the people is unjust to "us" and also to our fellows from the other side of the political spectrum.

\section{Exorcists' Regime as a Force for Legal Justice}

Exorcists' Regime (1978) was a translation of Arthur Miller's The Crucible by Watchara Kuptawatin. The play questions the relationship between justice and law from the very beginning with the existence of Tituba, a black slave. According to Johnson $(2017,59)$, in New England at that time, possessing slaves through purchase was lawful.

It is well-known that Miller wrote The Crucible to reflect American society in the 1950s during the time of McCarthyism and the House Un-American Activities Committee. People suspected and, often wrongly, accused one another of being communists. This hysteria was like that in Salem during the 1692 witchhunts. Miller $(2009,42)$ explains the similarity between prosecuting "communists" and "witches" as follows:

[S]ince the enemy was first and foremost an idea, normal evidentiary proof of disloyal actions was either de-emphasised, left in limbo or not required at all, and indeed, finally, actions became completely irrelevant. In the end, the charge itself, suspicion itself, all but became the evidence of disloyalty. Most interestingly, in the absence of provable disloyal actions both societies reached for very similar remedies. [...] To the rescue came not an Attorney General's List, but a piece of poetry smacking of both legalistic and religious validity - it was called "Spectral Evidence." $[\ldots][\mathrm{N}]$ ow, with society under this hellish attack, the fateful decision was made to allow it in, and the effect was the bursting of a dam.

Communists and witches committed what can be called thought-crime and the play warns the reader about the injustice of prosecuting this kind of crime. 
In the play, "Spectral Evidence" puts many innocent people in jail. A sad irony of the story is that the court refuses to take a name list of people who maintain that Elizabeth and others are good Christians on the ground that "people who are not present in the court" cannot be used as witnesses (3.148). ${ }^{5}$ However, the court accepts Abigail's accusation that Elizabeth's "evil spirit" attacked her, as evidence, though the "evil spirit" not only cannot be called to the court to be interrogated but does not even exist.

Danforth, the Supreme Judge, thinks accepting spectral evidence is justifiable in the case of witchcraft because the witch naturally will not accuse herself. Thus, "the most trustworthy is the victim" (3.156-157). He believes that God is revealing the truth to him through the "innocent children" (3.139). His assumption is that what he sees suggests the truth inside and what someone did reveals his or her true, unchangeable nature.

This assumption proves to be wrong. The only time that Danforth seems to seriously doubt Abigail is when she is accused of fornication with John Proctor, Elizabeth's husband. In Danforth's mind, if someone committed an immoral thing once, that person is irredeemably the enemy of God. Danforth proves this accusation by interrogating Elizabeth.

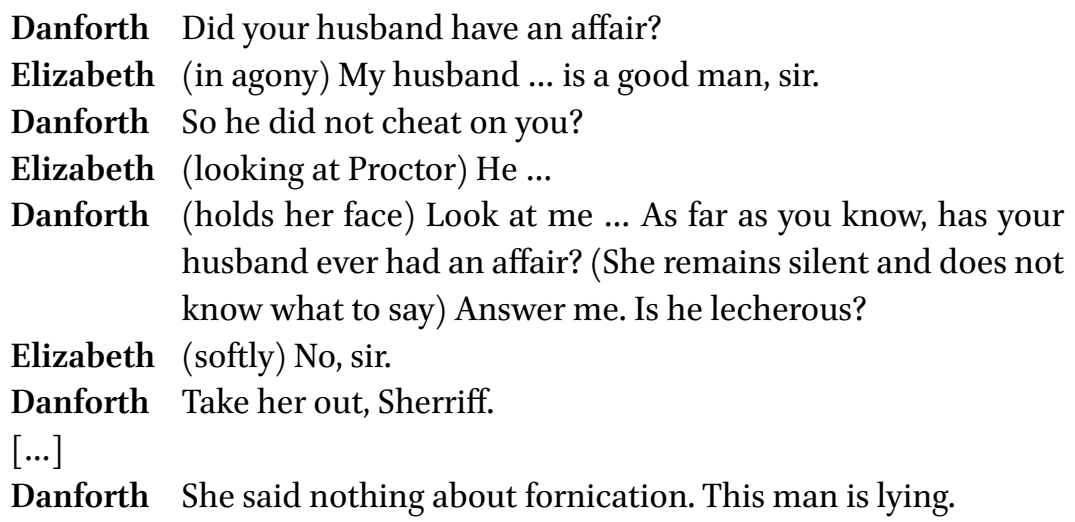
$(3.177)$

Danforth fails to understand that Elizabeth's hesitation is proof that Proctor and Abigail had an affair. If they had not, she would surely reject the suggestion right away. For Elizabeth, what Proctor did was wrong but that deed does not define who he is. When Danforth asks whether he is lecherous, Elizabeth

5 Miller, A. 1978. Exorcists' Regime, translated by Watchara Kuptawatin. Bangkok: Duangkamol. All quotations from or references to the translated play will be to this edition and the act and page number will be referenced parenthetically. 
interprets it as if he were asking whether her husband is a good Christian, so, she says he is. Danforth interprets that answer as a refusal of the fornication charge, which is not what Elizabeth is suggesting. He then wrongly concludes that the accusation against Abigail is a lie. Danforth also wrongly judges the accusations that Mary and Abigail make against each other. It is not always easy to judge whether a person is a good citizen or a threat from what he/she said, thought or did one time. As Miller $(2010,66)$ concludes after studying documents on the Salem witch trials, when the state tries to judge the value of one's citizenship, "no one is safe".

Moreover, the play reveals the injustice embedded in the legal system. Injustice may happen because of an officer's bias as in the case of Elizabeth. Cheever, the clerk of the court, suspects that the accusation against her is true so he reads things into evidence. When it turns out that the "voodoo" poppet in the house, Cheever's "clear proof" of Elizabeth's guilt (2.118), does not belong to Elizabeth but to Mary, Cheever turns to another form of evidence. He takes Elizabeth's enraged cry that she wants to "take [Abigail] out of the world" (2.121) as the proof of her wrong doing.

Nevertheless, the whole tragedy is clearly not the fault of an individual. As many of the officers insist, they merely "follow the orders" (2.115) and there is nothing they can do. In fact, the whole system is unjust. No officer or staff in the court questions the law which authorizes violence against "witches". It is worth remembering that although the play is mainly about the legal process, no one talks about "justice", especially in the sense of social justice. Danforth uses the word "justice" one time. When Hale asks him to grant the defendants an opportunity to consult with lawyers, Danforth asks Hale back, "Do you have doubt on my justice?" (3.156), and tells Proctor, "a pure heart needs no lawyer" (3.146).

To Danforth, justice means legitimate authority and, since the system is one which authorizes interested parties, the system itself becomes "justice". This perception unfairly de-emphasizes the rights of defendants. People like Francis and Proctor do not receive any legal advice and have difficulty in having the judges give them a hearing. The jail is "dark" (4.191) and "smelly" (4.195).

Under this system, what people who are authorized want becomes "justice". In the case of Danforth and his men, the thing they want is confession, which legitimizes what they are doing. In the end, confession becomes the only thing that matters. They deploy a number of tactics, including threatening, blackmailing and torturing, to elicit confessions. Imprisonment transforms Proctor into another man. He is "filthy", his eyes are "misty" and he walks with difficulty (4.209).

What Judge Hathorne says in the last act fully emphasizes the injustice of Salem's legal system. According to him, the execution of "the witches" was done 
for "the satisfaction of the villagers" and for "peace" (4.200). The purpose of Salem's legal system is not to advance social justice but to maintain the status quo.

The court in this play is, as Griffin $(2009,67)$ puts it, an "authoritarian" court, which is, by nature, hostile towards social justice. At that time, Salem was ruled by theocracy. The judges claimed that they worked for God. Danforth even declares that he is willing to hang thousands of people to follow the law of God (4.204). His ideology is that of fundamentalists who, as Bauman $(1997,184)$ explains, attach themselves to "the indubitably supreme authority, an authority to end all other authorities". Since the court claims that they are working for the "supreme authority", other values, like transparency or humanity, are ignored. When Giles interrupts the court in order to present a new piece of evidence, what the court is concerned about is not whether that proof is reliable but whether Giles should be charged for contempt of court. In this court, only the voice of authority matters.

Nevertheless, after all, the judges are not God. They are ordinary men who are full of wiles and ignorance. Danforth is obviously biased against Mary and Proctor. While interrogating her, Danforth thinks she looks "possessed" (3.182). It is also clear that Danforth and his men are trying to convince Proctor and others to confess not because they do not want to hang anyone but because they know that if no one confesses, people will doubt whether they are really guilty and, eventually, "the whole town will come at" them (4.200).

Thus, when Proctor says that he will confess, Judge Hathorne "runs out" and "shouts down the corridor" (4.218). He does this in order to pile pressure on other people who still refuse to confess to a crime they did not commit. Finally, Proctor tears up his confession because the judges are planning to place it on the church's door in order to justify the execution of others. The judges apparently are serving not God but themselves.

The irony is that this authoritarian court tries hard to bring order to Salem but what it really brings is chaos. As Cheever and Hale report, "cows are wandering on the roads because their owners are in jail and there is much argument who will have them" (4.196), and "there are many orphans. [...] Crops are rotting" (4. 196, 205-206). In the end, people who declare themselves to be good Christians are the ones who shatter love between neighbors, and the law brings disorder.

Exorcists' Regime suggests the inconvenient truth that the law can be the root of injustice. By urging people to think about problems in the legal system, the play can be a force for justice in Thailand. This assumption is confirmed by the reactions of spectators towards the original play's first production. According to Miller (cited in Abbotson 2007, 109), on the day that Ethel and Julius Rosenberg were being executed, "after Proctor's execution the audience 
silently rose to its feet with heads bowed for several minutes". As Clune (2016, 164) maintains, today people are still arguing whether Ethel was really a spy. The event suggests that this play can make people identify with common people whose rights and lives are threatened by an authoritarian regime.

Exorcists' Regime reflects serious legal problems in Thailand. Inaccessibility to legal consultation and lawyers, which Proctor faces, is an issue that poor people still face in Thailand. Like people in Salem, during a prolonged political crisis many Thai people have questions over the credibility of the courts and independent organizations. The play reminds us that the judicial system will be a force for peace and order only if people have trust in them.

Moreover, as Kuptawatin (cited in Phaolaungthong, 1978: 16) explains:

The theme of this play is still much alive. That is to say that it can be a lesson for every society. Even today religious beliefs, political beliefs and others are things that are making people kill one another time and time again in every corner of the world. The clearest and nearest [example] is in Thailand.

What the translator had in mind is clearly the Thammasat University Massacre and its aftermath when "communists" were continually arrested. The translator used his translation as a means to urge people to stay clear of hysteria and stop using violence. His warning is very relevant to what happens in Thailand. During times of political crisis, Thailand is rather like Salem. Violence is often used against "wrongdoers". The law becomes a means to get rid of political opponents or people who hold "wrong" ideas. However, the play shows us that, as Hale does about his belief in witchcraft, people can change their minds, and prosecuting thought-crime is dangerous because it relies on interpretation, which is prone to mistakes and abuses. Raising awareness of legal problems in Thailand, through discussing legal issues in the play in the classroom, is undoubtedly helpful in advancing social justice.

The four translated plays encourage the reader /audience to think about social justice in terms of cultural, economic, political and legal aspects. They directly and indirectly show the harmful effects of inequality and the necessity for establishing a society in which disadvantaged people are given help, everyone is equal, and opportunities are open to all. Venice Vanit demonstrates the destructive effects of racial and cultural discrimination. The Good Person 
of Szechwan shows the corruption and injustice which are the result of economic inequality and exploitation. Antrakani offers the audience/reader a chance to listen to people with different political views, which is good practice for creating an inclusive and tolerant society. Exorcists' Regime illustrates the negative effects of having an authoritarian court and a self-serving legal system. These issues are relevant to social problems in Thailand. Thus, the plays can be used as a force to raise a form of social awareness which is favorable to social justice. Writing a critique, teaching or performing these plays with an emphasis on their social issues can play a part in creating a fair and just society.

Nonetheless, social justice was not the focus of previous criticisms of these translated plays. In the case of Venice Vanit, they even undermine social justice. Moreover, there are too few criticisms by Thai academics of the four plays and most of them were written more than ten years ago. Writing critiques of these plays and translating new plays, which have implications for social justice, will be beneficial not only to the Thai academic community but also to Thai society. Furthermore, conducting research on literature which makes a connection with important issues in Thailand is a project that will be worthwhile to undertake in the future.

\section{Acknowledgements}

This research article is the outcome of a research project entitled Translated Plays as a Force for Social Justice sponsored by the Thailand Research Fund. The views and opinions expressed in this article are those of the authors only and do not represent the views and opinions of the Thailand Research Fund.

\section{References \\ (In Thai)}

Aeusriwongb, Nithi. 2012. Khwam Mai Ru Rueang Setthasat [(Uninformed) Knowledge on Economics]. Bangkok: openbooks. (In Thai)

Ananapibut, Pan. 2014. "Kanpatirup Rabop Phasi phuea Sangkhom Thai Samoena [Tax Reform for Equality in Thai Society]." In Su Sangkhom Thai Samoena [For Equality in Thai Society], edited by Pasuk Phongpaichit, 265-300. Bangkok: Matichon. (In Thai)

Anouilh, Jean. 1976. Antrakani, translated by Mattani Rutnin and Suchawadee Tantawanit. Bangkok: Duangta. (In Thai) 
Archavanitkul, Kritaya and Kulapa Vajanasara. 2008. "Nai Khwamlaklai haeng Chintanakan Khwam Pen Thai [Diversity in the Imagined "Thainess"]." In Chintanakan Khwam Pen Thai [Imagined "Thainess"], edited by Kritaya Archavanitkul, 13-58. Bangkok: Institute for Population and Social Research, Mahidol University. (In Thai) Asvabhahu. 1985. Phuak Jew haeng Burapha Thit lae Mueang Thai Chong Tuen Thoet [The Jews of the Orient and Wake Up, Siam]. Bangkok: King Vajiravudh Memorial Foundation. (In Thai)

Banchoetsin, Banchong. 1974. Sinlapa Wannakhadi kap Chiwit [Literary Art and Life]. Bangkok: Charoenwitkanphim. (In Thai)

Brecht, Bertolt. 2005. The Good Person of Szechwan, translated by Duangporn Pongsopavichit. Chiang Mai: Faculty of Humanities, Chiang Mai University. (In Thai)

Chancharoensuk, Patama. 2011. "Kanmueang lae Khwam Pen Kanmueang nai Bot Phraratchaniphon Plae "Venice Vanit" [Politics and the Political in Venice Vanich by H.M. King Rama vI]." PhD diss., Thammasat University. (In Thai)

Chantornvong, Sombat. 2004. Botphichan wa duai Wannakam Kanmueang lae Prawattisat [Essays on Political Literature and History]. Bangkok: Khopfai. (In Thai)

Charoensin-o-larn, Chairat. 2008. Phasa kap Kanmueang / Khwam Pen Kanmueang [Language and Politics / the Political]. Bangkok: Thammasat University Press. (In Thai)

Department of Curriculum and Instruction Development. 1984. Nang Sue An Kawi Niphan Rueang Venice Vanit. [Handbook for Reading Venice Vanit]. Bangkok: Kurusapa Press. (In Thai)

Klinchang, Parilak. 2001. Phonkrathop khong Kanlakhon Brecht thi Mi to Lakhon Thai Ruamsamai: Koranisueksa Klum Phrachan Siao [The Impact of Brecht's Drama on Thai Contemporary Theatre: A Case Study of the Crescent Moon Group]. Master's Thesis, Chulalongkorn University. (In Thai)

Limthongkul, Sonthi. 2011. "Sonthi pluk muanchon sang sangkhom mai." Manager Weekly. http://www.manager.co.th/Politics/ViewNews.aspx? NewsID=9510000066801.

Malakula, Pin. 1996. Ngaan Lakhon khong Phrabaat Somdet Phra Ramathibodee Srisintara Mahavajiravudh Phra Mongkutklao Chao Paendin Siam [Introduction to the Dramatic Activities of His Majesty King Vajiravudh]. Bangkok: Thaiwattanaphanit. (In Thai)

Meesuk, Nida. 2000. Wannakhadi Kanlakhon [Dramatic Literature]. Songkhla: Thaksin University, Faculty of Humanities and Social Sciences. (In Thai)

Miller, Arthur. 1978. Exorcists' Regime, translated by Watchara Kuptawatin. Bangkok: Duangkamol. (In Thai)

Nagavajara, Chetana. 1983. Wannakam Lakhon khong Bertolt Brecht: Kansueksa Choeng Wikhro [Dramatic Literature of Bertolt Brecht: A Critical Study]. Bangkok: The Foundation for the Promotion of Social Sciences and Humanities Textbooks Project. (In Thai) 
Nagavajara, Chetana. 2004. "An Suepnueang Ma Chak Antrakani [A Review on Antrakani]." In Phalang Kanwichan: Sinlapa Kanlakhon [Criticism as an Intellectual Force: Drama ], edited by Parichat Jungwiwattanaporn, 723-729. Bangkok: The Thailand Research Fund. (In Thai)

Pakeerut, Woracet. 2015. Duai Kotmai lae Udomkan [With the Law and Commitment]. Bangkok: Shine. (In Thai)

Pantoomkomol, Sodsai. November 1985. "Sinlapa Kanlakhon lae Naeo Kanlakhon khong Bertolt Brecht [Drama and Dramatic Techniques of Bertolt Brecht]." Banmairuroi 1 (10): 72-82. (In Thai)

PDRC Foundation. 2017. "Khosanoenae rueang kan patirup prathet." PDRC Foundation. http://www.pdrcfoundation.org/index.php/newsandactivity/40-2017-0320-03-58-34 (In Thai)

Phaolaungthong, Ratsame. 1978. "Bot Klao Nam: America Yathok Mophi Khrong Mueang [Introduction: America in the Time of Witch-Hunts]." In Exorcists' Regime, translated by Duangporn Pongsopavichit, 9-31. Bangkok: Duangkamol. (In Thai)

Phaolaungthong, Ratsame. 2004. "Lakhon Phanthang Antrakani Phu Ma Lang Kanwela [Antrakani: A Mongrel Production that Fell Behind]." In Phalang Kanwichan: Sinlapa Kanlakhon [Criticism as an Intellectual Force: Drama], edited by Parichat Jungwiwattanaporn, 65-170. Bangkok: The Thailand Research Fund. (In Thai)

Phiriyarangsan, Sangsit. 2006. Khorapchan Rabop Thaksin [Corruption of Thaksinocracy]. Bangkok: Ruam duai chuai kan chut.

Phi Tu. 2008. Phi Tu talk show. Manager Weekly. http://www.manager.co.th/mgrweekly /viewnews.aspx?newsID=9510000123480 (In Thai)

Phongpaichit, Pasuk. 2014. Khwammangkhang Amnat Khwammaithaothiam [Wealth, Power, Inequality]. In Su Sangkhom Thai Samoena [For Equality in Thai Society], edited by Pasuk Phongpaichit, 13-35. Bangkok: Matichon.

Phoprom, Apiradee. 2007. Panha Khwammaisamoephak nai Krabuankan Yutitham thi Prachachon Dairap [Inequality in Judicial Process Affect on People]. Bangkok: The Thailand Research Fund. (In Thai)

Prompan, Jatuporn. 2016. Jatuporn lan chutyuen no po cho. Thairath Online. https:// www.thairath.co.th/content/715163. (In Thai)

Rungsakul, Nawaporn. 2017. Bueanglang Ngoentra lae Naithanakhan [Behind the Scenes of Finance and Bankers]. Bangkok: Knowledge. (In Thai)

Rutnin, Mattani. 2001. Botnam [Introduction]. In Plae Plaeng lae Praerup Bot Lakhon [Translating, Revising and Transforming Plays], 16-18. Bangkok: Siam. (In Thai)

Saengkanokkul, Piyabutr. 2016. Ratthathammanun: Prawattisat Khokhwamkhit, Amnat Sathapna lae Kanplianphan [Constitution: History of Ideas, Pouvoir Constituant, and Transitions]. Bangkok: Sameskybooks. (In Thai)

Sangtaksin, Yuporn. 2005. "Bot Soem Thai Venice Vanit Phraratchaniphon nai Phrabatsomdet Phra Mongkut Klao Chaoyuhua [A Supplementary Chapter on 
Venice Vanit by His Majesty King Vajiravudh]." In Venice Vanit, 214-232. Bangkok: Aksancharoenthat. (In Thai)

Satha-Anand, Suwanna. 2009. Khamnam [Preface]. In Khwampentham choeng Wannasin [Literary Justice], edited by Suwanna Satha-Anand, $5^{-12}$. Bangkok: Wiphasa. (In Thai)

Satitniramai, Apichat, Yukti Mukdawijitra and Niti Pawakapan. 2013. Thopthuan Phumithat Kanmueangthai [Re-Examining the Political Landscape of Thailand]. Chiang Mai: Public Policy Studies Institute Foundation, Chiang Mai University. (In Thai)

Setabutr, Noranit. 2015. Ratthathammanun kap Kanmueang Thai [Constitution and Thai Politics]. Bangkok: Thammasat University Press.

Shakespeare, William. 2005. Venice Vanit, translated by Vajiravudh, the King. Bangkok: Aksoncharoenthat. (In Thai)

Suppha, Phisanu. 25 November 1979. "Khondithisechaun [The Good Person of Szechwan]." Siamrath Weekly 22.26: 36-37. (In Thai)

Suveeranont, Pracha. 2015. Attalak Thai: Chak Thai su Thai Thai [Thai Identity: From Thai to Vernacular Thai]. Bangkok: Sameskybooks. (In Thai)

Tamthai, Mark and Somkiat Boonchu. 2008. "Nayobai Khwammangkhonghaengchat Changwat Chaidaen Phaktai Priapthiap nai Rop 30 Pi [A Comparison of National Security Policies in the Deep South Provinces in 30 Years]." In Phaendin Chintanakan: Rat lae Kankaekhai Panha Khwamrunraeng nai Phaktai [Imagined Land: State and Solutions on Violence in the South], edited by Chaiwat Satha-Anand, 53-107. Bangkok: Matichon. (In Thai)

Tejapira, Kasian. 2010. Songkhram rawang Si: Kon Thueng Chut thi Mai At Huan Klap [Wars between Colors: When There was a Way Back]. Bangkok: openbooks. (In Thai)

Tejapira, Kasian. 2015. Boriphok Khwam Pen Thai [Consuming Thainess]. Bangkok: Sameskybooks. (In Thai)

Thongtawee, Chollada. 1990. Kansueksa Priapthiap Kanchai Tamnan Antigone Phuea Sanoe Thatsana Thang Sangkhom lae Kanmueang nai Botlakhon khong Sophocles, Botlakhon khong Anouilh lae Botlakhon khong Mattani Rutnin lae Suchawadee Tantawanit [A Comparative Study of the Use of the Antigone Myth in Presenting the Social and Political Ideas in the Plays of Sophocles, Anouilh and Mattani Rutnin and Suchawadee Tantawanit]." Master's thesis, Chulalongkorn University. (In Thai)

Ua-amnoey, Jutharat and Kamonthip Khatikarn. 2011. Khrongkan Wethi Khwamkhit phuea Kan Patirup Krabuankanyutitham Thai [Thai Criminal Justice Reform Forum]. Bangkok: Law Reform Commission of Thailand. (In Thai)

Uwanno, Borwornsak, et al. 200o. "Thittang Krabuankan Yutitham Thai nai Satawat Na [Directions of Thai Judicial Process in the Next Century]." In Thitthang Krabuankan Yutitham Thai nai Satawat Na [Directions of Thai Judicial Process in the Next Century], 
edited by Kittipong Kittiyarak, 19-40. Bangkok: The Thailand Research Fund. (In Thai)

Wasi, Prawet. 2000. "Prachachon Phueng Khatwang Arai chak Krabuankan Yutitham [What People Should Expect from the Judicial Process].” In Thitthang Krabuankan Yutitham Thai nai Satawat Na [Directions of Thai Judicial Process in the Next Century], edited by Kittipong Kittiyarak, 7-18. Bangkok: The Thailand Research Fund. (In Thai)

Winichakul, Thongchai. 2017. Khon Thai / Khon Uen: Wa duai Khon Uen khong Khwam Pen Thai [Thais / Others: On Others in Thainess]. Bangkok: Sameskybooks. (In Thai) Yuvajita, Pachee. 20o9. "Phaplak Phokha Yio nai Botlakhon Yuk Alisabithan [The Images of Jewish Merchants in Elizabethan Plays]." In Khwampentham choeng Wannasin [Literary Justice], edited by Suwanna Satha-Anand, 1-41. Bangkok: Wiphasa. (In Thai)

\section{(In English)}

Abbotson, Susan. 2007. Critical Companion to Arthur Miller: A Literary Reference to his Life and Work. New York: Facts on File.

Anouilh, Jean. 1946. Antigone, translated by Lewis Galantière. New York: Random House.

Bauman, Zygmunt. 1997. Postmodernity and its Discontents. New York: New York University Press.

Brecht, Bertolt. 2014. Brecht on Theatre, edited by Marc Silberman, Steve Giles and Tom Kuhn. London: Bloomsbury.

Clune, Lori. 2016. Executing the Rosenbergs: Death \& Diplomacy in a Cold War World. Oxford: Oxford University Press.

Deville, Taylor. 5 April 2016. Review: "The Good Person of Setzuan" at The Towson University Department of Theatre Arts. DC Metro. https://dcmetrotheaterarts .com/2016/04/05/review-the-good-person-of-setzuan-towson/.

Eddershaw, Margaret. 2002. Performing Brecht. New York: Taylor \& Francis.

Garden, Nancy. 2007. Annie on my Mind. New York: Farrar, Straus, Giroux.

Griffin, Alice. 2009. “The Individual versus the Law.” In Justice in Arthur Miller's The Crucible, edited by Claudia Durst Johnson, 67-73. Detroit: Greenhaven.

Hartnoll, Phyllis. 1983. The Oxford Companion to the Theatre. Oxford: Oxford University Press.

Jameson, Fredric. 1998. Brecht and Method. London: Verso.

Johnson, Claudia Durst. 2017. Daily Life in Colonial New England. Santa Barbara: Greenwood.

Kahn, Erin. 18 May 2017. Review: Antigone. Stage Buddy. https://stagebuddy.com /theater/theater-review/review-antigone. 
Mahood, Molly. 2003. The Merchant of Venice. Cambridge: Cambridge University Press. Marx, Karl. 1965. Pre-Capitalist Economic Formations, translated by Jack Cohen. New York: International Publishers.

Marx, Karl. 1976. “Theses on Feuerbach." In Ludwig Feuerbach and the End of Classical German Philosophy, 61-65. Peking: Foreign Languages Press.

McDougall, Julie. 2011. "Maori Take on Shakespeare: The Merchant of Venice in Aotearoa/New Zealand." Multicultural Shakespeare: Translation, Appropriation and Performance. 8 (23): 93-106.

McPherson, James. 1988. Battle Cry of Freedom. Oxford: Oxford University Press.

Mill, John. Stuart. 2001. Utilitarianism. Ontario: Kitchener.

Miller, Arthur. 2009. "Witchcraft and Subversion." In Justice in Arthur Miller's The Crucible, edited by Claudia Durst Johnson, 36-43. Detroit: Greenhaven.

Miller, Arthur. 2010. "Arthur Miller Discusses First Steps in Writing the Crucible." In Bloom's Guides: Arthur Miller's the Crucible, edited by Harold Bloom, 64-67. New York: Bloom's Literary Criticism.

Morritt, Robert. 2011. Lost in the Antebellum. Newcastle: Cambridge Scholars.

Nagavajara, Chetana. 1996. Comparative Literature from a Thai Perspective: Collected Articles 1978-1992. Bangkok: Chulalongkorn University Press.

Paine, Thomas. 1995. Rights of Man, Common Sense and other Political Writings. Oxford: Oxford University Press.

Rawls, John. 1999. A Theory of Justice. Cambridge: Harvard University Press.

Rancière, Jacques. 2009. "The Aesthetics Dimensions: Aesthetics, Politics, Knowledge." Critical Inquiry 36 (1): 1-19.

Rancière, Jacques. 2010. Dissensus: On Politics and Aesthetics, translated by Steven Corcoran. London: Continuum.

Sidney, Philip. 200o. "The Defense of Poesy." In Theatre / Theory / Theatre, edited by Daniel Gerould, 119-127. New York: Applause.

Sinfield, Allan. 1983. “ Introduction.” In Society and Literature: 1940-1970, edited by Alan Sinfield, 1-10. Oxon: Routledge.

Terry, Ellen. 1908. The Story of my Life: Recollections and Reflections. New York: Doubleday \& Page.

Tungtang, Paradee. 2011. Shakespeare in Thailand. PhD diss., University of Warwick, Coventry. 